\title{
Turning Off Estrogen Receptor $\beta$-Mediated Transcription Requires Estrogen-Dependent Receptor Proteolysis $\nabla$
}

\author{
Yukiyo Tateishi, ${ }^{1} \dagger$ Raku Sonoo, ${ }^{2} \dagger$ Yu-ichi Sekiya, ${ }^{1}$ Nanae Sunahara, ${ }^{1}$ Miwako Kawano, ${ }^{1}$ \\ Mitsutoshi Wayama, ${ }^{1}$ Ryuichi Hirota, ${ }^{2}$ Yoh-ichi Kawabe, ${ }_{1}^{1}$ Akiko Murayama, ${ }^{1}$ \\ Shigeaki Kato, ${ }^{3}$ Keiji Kimura, ${ }^{1}$ and Junn Yanagisawa ${ }^{1,2 *}$ \\ Graduate School of Life and Environmental Sciences, University of Tsukuba, Tsukuba Science City, Ibaraki 305-8572, Japan ${ }^{1}$; \\ Ankhs Incorporated, Tsukuba Industrial Liaison and Cooperative Research Center, University of Tsukuba, Tsukuba Science City, \\ Ibaraki 305-8577, Japan'; and Institute of Molecular and Cellular Biosciences, \\ University of Tokyo, Bunkyo-ku, Tokyo 113-0032, Japan ${ }^{3}$
}

Received 25 April 2006/Returned for modification 12 June 2006/Accepted 17 August 2006

\begin{abstract}
Recent studies have shed light on the ligand-dependent transactivation mechanisms of nuclear receptors (NRs). When the ligand dose is reduced, the transcriptional activity of NRs should be downregulated. Here we show that a ubiquitin-proteasome pathway plays a key role in turning off transcription mediated by estrogen receptor $\beta(E R \beta)$. ER $\beta$ shows estrogen-dependent proteolysis, and its degradation is regulated by two regions in the receptor. The $\mathrm{N}$-terminal 37 -amino acid-region is necessary for the recruitment of the ubiquitin ligase, i.e., the carboxyl terminus of HSC70-interacting protein (CHIP), to degrade ER $\beta$. In contrast, the C-terminal $F$ domain protects ligand-unbound ER $\beta$ from proteolysis to abrogate proteasome association. Suppression of CHIP by interfering RNA inhibited this switching off of receptor-mediated transcription when the ligand dose was reduced. Our results suggest that after ligand withdrawal, the active form of the NR is selectively eliminated via ligand-dependent proteolysis to downregulate receptor-mediated transcription.
\end{abstract}

Estrogen is a growth factor that stimulates cell growth and differentiation in diverse tissues. Dramatic changes in the levels of estrogen in the blood occur during the normal human menstrual cycle. During the first 7 to 10 days, the level of estrogen is low. In the middle of the cycle (days 11 to 15), it rises and then falls abruptly. The effects of estrogen are mediated through the estrogen receptors (ERs), ER $\alpha$ and ER $\beta$, which function as ligand-induced transcription factors and belong to the nuclear receptor (NR) superfamily $(2,5,12,20,31$, $33,41,49)$. When the estrogen level is high, estrogen binds to ERs to activate the transcription of target genes. This induces the ligand-binding domain (LBD) to undergo a characteristic conformational change, whereupon the receptor dimerizes, binds to DNA, and subsequently stimulates gene expression (10). ER $\alpha$ is stimulated by two distinct activation regions, activation function 1 (AF-1) and $\mathrm{AF}-2$, which are located in the LBD and exert ligand-dependent transcriptional activity. Crystal structure analysis of ERs and other NRs has revealed the presence of 12 conserved helices in their LBDs (46). The LBD forms a structure described as a sandwich of $12 \alpha$-helices (helices 1 to 12 ) with a central hydrophobic ligand-binding pocket. Helix 12 , the most Cterminal of these helices, has been identified as the critical core (AD core) of the AF-2 function of the receptor and plays an important role in coactivator binding to the ligandbound receptor $(6,19,24,25,33,35,39,43,45,55,56)$.

\footnotetext{
* Corresponding author. Mailing address: Graduate School of Life and Environmental Sciences, University of Tsukuba, Tsukuba Science City, Ibaraki 305-8572, Japan. Phone: 81-29-853-6632. Fax: 81-29-8534605. E-mail: junny@agbi.tsukuba.ac.jp.

$\dagger$ These authors contributed equally to this work.

${ }^{\nabla}$ Published ahead of print on 28 August 2006.
}

When the level of estrogen is decreased, receptor-mediated transcription should be downregulated. Because the response to estrogen is tightly controlled, the downregulation of ERmediated transcription should also be tightly regulated. Although such regulation of the NRs has generated intense interest, the molecular mechanisms regulating these processes are not understood (38). To switch off transcription, there are at least two possible mechanisms. The first involves the dissociation of ligands from the hormone-binding pocket of the receptor. However, the dissociation rate of the ligand from its receptor is very low, because the receptor locks the hormone within its activation pocket and covers it with coactivators (16). Another possible mechanism is the rapid degradation of active receptors. Several nuclear receptors, such as the ER and those for progesterone, glucocorticoid, thyroid hormone receptor, retinoid $\mathrm{X}$, and retinoic acid, are ubiquitinated and degraded in the course of their nuclear activities $(8,11,13,26,29,32,36$, $47,51,57)$. These degradation steps might be involved in turning off NR-mediated transcription.

Evidence now suggests that proteasome-dependent degradation of receptors is necessary for the activation of these receptors (38). Moreover, this requires NR-mediated transcriptional activity, implying that the degradation and the transactivation of NRs are mutually independent processes. In the ubiquitin-proteasome pathway, proteins destined for degradation are conjugated by polyubiquitin chains, in which one ubiquitin molecule is conjugated by another through one of its seven lysine residues, typically K48. These polyubiquitin chains are then recognized by the regulatory complex of the $26 \mathrm{~S}$ proteasome.

Here we show that there is a ubiquitin-proteasome pathway for $E R \beta$ that is not coupled to transactivation. To investigate this, we purified the ubiquitin ligase complex for ER $\beta$ and 
identified a protein complex containing the carboxyl terminus of heat shock cognate 70 (HSC70)-interacting protein (CHIP) (1). CHIP binds directly to the N-terminal 37-amino-acid region of ER $\beta$ and ubiquitinates it to induce ER $\beta$ degradation. In contrast, the $\mathrm{C}$-terminal $\mathrm{F}$ domain inhibits the binding of proteasome to the receptor and protects it from proteolysis in the absence of estrogen. Suppression of CHIP by interfering RNA (RNAi) inhibited the switching off of receptor-mediated transcription that occurs when the ligand dose is reduced. Our results suggest that ligand-dependent degradation selectively and rapidly eliminates the active form of a nuclear receptor to downregulate receptor-mediated transcription after ligand withdrawal.

\section{MATERIALS AND METHODS}

Expression vectors. The ER $\alpha / \beta$ and CHIP expression plasmids and their deletion mutants have been described previously (48). ERE-TATA-Luc and ERE-TATA-LucCP were constructed by inserting three consensus estrogen response elements into a luciferase reporter plasmid encoding a TATA box, pGL3Basic or phRG(R2.2)-Basic. pGL3-Basic, phRG(R2.2)-Basic, and pGL3-Control vectors were purchased from Promega (Madison, WI).

Antibodies. Anti-FLAG-M2 mouse monoclonal antibody (Sigma, St. Louis, MO), anti-hemagglutinin (HA) mouse monoclonal antibody (Roche), anti-human ER $\alpha$ antibody (Chemicon, Temecula, CA), anti-human ER $\beta$ antibody (PPMX), and anti-glyceraldehyde-3-phosphate-dehydrogenase mouse monoclonal antibody (American Research Products, Inc.) were used at appropriate dilutions, according to the manufacturers' instructions. A rabbit polyclonal antibody directed against CHIP was provided by T. Chiba (Tokyo Metropolitan Institute of Medical Science).

Cell culture and transfection. MDA-MB231 breast cancer cells and human embryonic kidney 293 cells were routinely maintained in Dulbecco's modified Eagle's medium (DMEM) supplemented with 10\% fetal bovine serum (FBS). Twenty-four hours before transfection, the medium was changed to phenol red-free DMEM containing 4\% charcoal-stripped FBS. Transfection was performed using PerFectin transfection reagent (Gene Therapy Systems) or TransFast transfection reagent (Promega) according to the manufacturers' protocols. The cells were treated with or without MG132 $\left(10^{-6} \mathrm{M}\right)$ and estrogen $\left(10^{-8} \mathrm{M}\right)$. Twenty-four hours after the addition of estrogen, the cells were harvested and analyzed by Western blotting using the appropriate antibodies.

Coimmunoprecipitation and Western blotting. The 293 cells were transfected with the appropriate plasmids and lysed in TNE buffer $(10 \mathrm{mM}$ Tris- $\mathrm{HCl}[\mathrm{pH}$ 7.8], $0.5 \%$ Nonidet P-40 [NP-40], $0.15 \mathrm{M} \mathrm{NaCl}, 1 \mathrm{mM}$ EDTA, $1 \mu \mathrm{M}$ phenylmethylsulfonyl fluoride [PMSF], $1 \mu \mathrm{g} / \mathrm{ml}$ aprotinin). Extracted proteins were immunoprecipitated with antibody-coated protein A/G-Sepharose (Amersham) or anti-FLAG M2 agarose (Sigma). The bound proteins were separated by sodium dodecyl sulfate-polyacrylamide gel electrophoresis (SDS-PAGE), transferred onto polyvinylidene difluoride membranes (Millipore), and detected with the appropriate antibodies and secondary antibodies conjugated with horseradish peroxidase. Specific proteins were detected using an enhanced chemiluminescence Western blot detection system (Amersham).

Luciferase assay. For luciferase assays, ERE-TATA-Luc plasmids were cotransfected with expression vector encoding ER $\beta$ or its mutants. As a reference plasmid with which to normalize transfection efficiency, the pRSVBGAL vector or the pRL-CMV vector was cotransfected in all experiments. Twenty-four hours after transfection, the culture medium was replaced with fresh medium containing $0.2 \%$ FBS, either estrogen $\left(10^{-8} \mathrm{M}\right)$ or ethanol vehicle was added, and the cells were incubated for an additional $24 \mathrm{~h}$. Cell extracts were prepared, and luciferase assays were performed following the manufacturer's protocol (Promega). $\beta$-Galactosidase activity was measured to control for the efficiency of each transfection. Individual transfections, each consisting of triplicate wells, were repeated at least three times.

Protein purification. Glutathione $S$-transferase (GST) protein or an immobilized 37-amino-acid region that we designated the "domain required for degradation" (DRD) fused to GST (GST-DRD) was preincubated for $1 \mathrm{~h}$ at $4^{\circ} \mathrm{C}$ in GST-binding buffer (20 mM Tris- $\mathrm{HCl}$ [pH 7.9], $180 \mathrm{mM} \mathrm{KCl,} 0.2 \mathrm{mM}$ EDTA, 0.5 $\mathrm{mM}$ PMSF, and $1 \mathrm{mM}$ dithiothreitol) containing bovine serum albumin (BSA; 1 $\mathrm{mg} / \mathrm{ml}$ ). Bead-immobilized proteins were then incubated at $4^{\circ} \mathrm{C}$ for 6 to $10 \mathrm{~h}$ with 293 cell extracts. After the beads had been washed three times with GST buffer (GST-binding buffer with $0.1 \%$ NP-40), they were washed again with GST buffer containing $0.2 \% \mathrm{~N}$-lauroyl sarcosine. Proteins bound to the DRD were eluted with $15 \mathrm{mM}$ reduced glutathione in elution buffer $(50 \mathrm{mM}$ Tris- $\mathrm{HCl}$ [pH 8.3], 150 mM KCl, 0.5 mM EDTA, 0.5 mM PMSF, $5 \mathrm{mM} \mathrm{NaF,} \mathrm{0.08 \%} \mathrm{NP-40,} 0.5 \mathrm{mg} / \mathrm{ml}$ BSA, and $10 \%$ glycerol). Recombinant CHIP was expressed in Escherichia coli and purified using Ni-agarose.

Immunofluorescence. The 293 cells were grown on poly-L-lysine-coated 12well culture dishes and transfected with plasmids. Twenty-four hours after transfection, the cells were fixed with $4 \%$ paraformaldehyde in phosphate-buffered saline (PBS) for $10 \mathrm{~min}$ and permeabilized with Triton buffer $(50 \mathrm{mM}$ Tris-HCl [pH 7.5], 0.5\% Triton X-100, $150 \mathrm{mM} \mathrm{NaCl}, 2 \mathrm{mM}$ EDTA) for $15 \mathrm{~min}$. The cells in each well were blocked with PBS containing $1 \%$ BSA and $0.5 \%$ goat serum for $3 \mathrm{~h}$ at $37^{\circ} \mathrm{C}$. The cells were incubated with the appropriate antibody in PBS containing $1 \% \mathrm{BSA}$ for $2 \mathrm{~h}$ at $37^{\circ} \mathrm{C}$. After the cells had been washed with PBS, they were incubated with Alexa-Fluor-488-conjugated goat anti-rat immunoglobulin G or Alexa-Fluor-594-conjugated goat anti-mouse immunoglobulin G (Molecular Probes) for $1 \mathrm{~h}$ at $37^{\circ} \mathrm{C}$ and washed with PBS. The samples were mounted with Vectashield mounting medium (Vector Laboratories) and analyzed using a Keyence Biozero BZ-8000.

Pulse-chasing. The 293 cells were transfected with ERß, and $48 \mathrm{~h}$ after transfection the cells were labeled for $30 \mathrm{~min}$ at $37^{\circ} \mathrm{C}$ with $\left[{ }^{35} \mathrm{~S}\right]$ methionine $(50$ $\mu \mathrm{Ci} / \mathrm{ml})$ in methionine-free DMEM. The cells were then washed twice and incubated in DMEM containing $0.2 \%$ FBS for the indicated periods (chase). At each time point, cell lysates were immunoprecipitated with anti-ER $\beta$ antibody. The immunoprecipitates were resolved by SDS-PAGE and visualized by autoradiography. A phosphorimager was used to quantify the metabolically labeled ER $\beta$ present at each time point.

RNAi. The 293gp cells were transfected with pSINsi-hU6 vector (Takara) containing the target sequence of CHIP or LacZ (control) and with vesicular stomatitis virus-encoded envelope protein $\mathrm{G}$ to generate the small interfering RNA (siRNA) retroviral supernatant. MDA-MB-231 cells were transfected with retroviral supernatant in the presence of Polybrene $(8 \mu \mathrm{g} / \mathrm{ml})$. Twenty-four hours after transfection, the viral supernatant was replaced with fresh DMEM containing $10 \%$ FBS. The transfected cells were selected with G418 $(1 \mathrm{mg} / \mathrm{ml})$. The target sequences were 5'-GCACGACAAGTACATGGCGGA-3' for CHIP and 5'-GCTACACAAATCAGCGATT-3' for LacZ.

\section{RESULTS}

An N-terminal 37-amino-acid region is essential for ER $\beta$ degradation. The level of ER $\beta$ protein was reduced by the addition of estrogen to the MDA-MB-231 breast cancer cell line. This degradation was inhibited by the proteasome inhibitors MG132 (Fig. 1A) and lactacystin (data not shown). In a ubiquitination assay, ER $\beta$ was ubiquitinated in both the presence and the absence of estrogen (Fig. 1B). Thus, ER $\beta$ is degraded via ubiquitin-proteasome pathways. Preliminary biochemical study showed that a single K48-linked polyubiquitin chain is sufficient to target a substrate to the $26 \mathrm{~S}$ proteasome. Therefore, we investigated the ubiquitin linage of the chains using a ubiquitin mutant lacking specific lysines, Ub(K48R). HA-tagged ubiquitin (HA-Ub) or Ub(K48R) was transfected into 293 cells, and the level of ER $\beta$ protein and the ubiquitination status were determined by Western blotting using an anti-FLAG-M2 or an anti-HA antibody. Expression of $\mathrm{Ub}(\mathrm{K} 48 \mathrm{R})$ reduced the degradation (Fig. 1C) and the ubiquitination status (Fig. 1D) of ER $\beta$, suggesting that the polyubiquitin chains of ER $\beta$ are linked via K48. These results indicate that whereas ER $\beta$ is polyubiquitinated via K48 in ubiquitin in both the presence and the absence of estrogen, the proteolysis is estrogen dependent. Our observations imply that ubiquitination in itself is not the only way to regulate ER $\beta$.

To investigate the molecular mechanism by which ER $\beta$ is degraded, DNA sequences encoding truncated forms of $\mathrm{ER} \alpha$ or $\mathrm{ER} \beta$ were transfected into 293 cells, and the protein levels were examined by Western blot analysis. $\operatorname{ER} \alpha(\Delta 181)$, which does not contain the $\mathrm{A} / \mathrm{B}$ domain, still underwent 
A

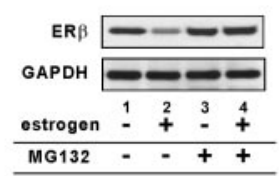

B

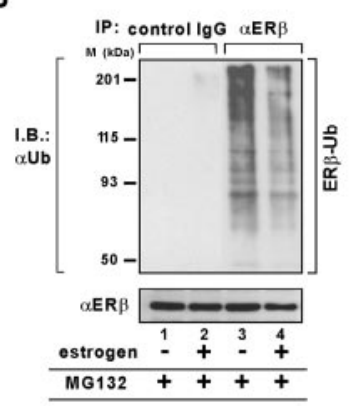

C

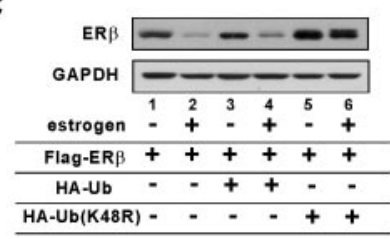

D

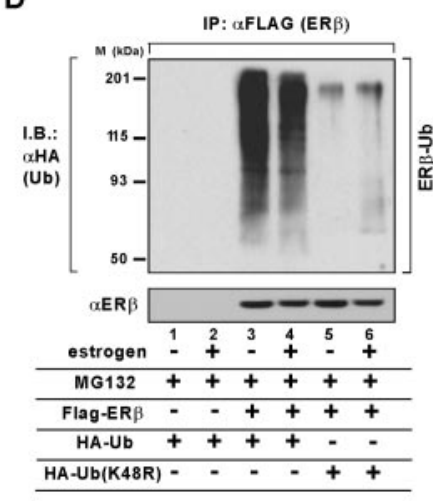

A

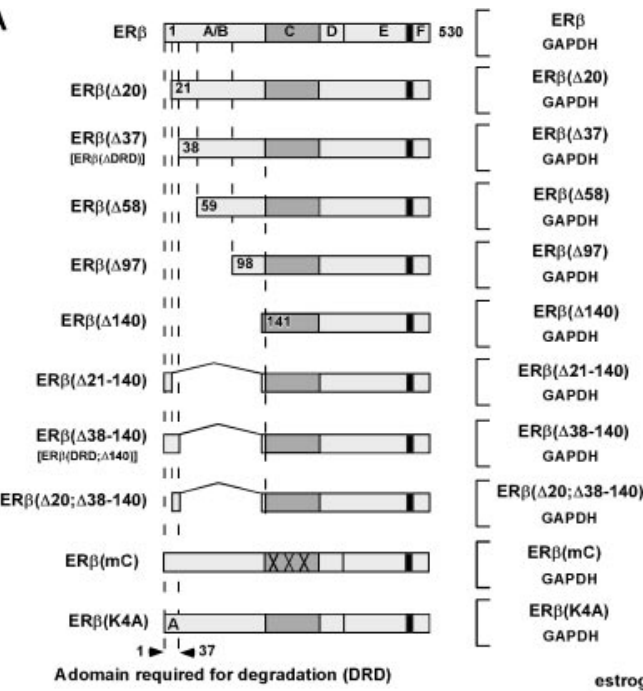

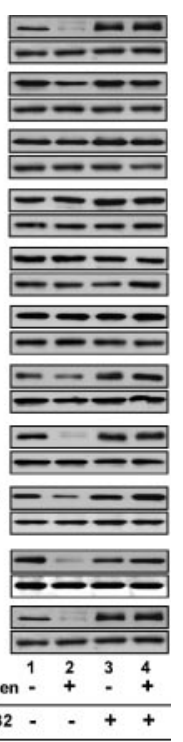

B

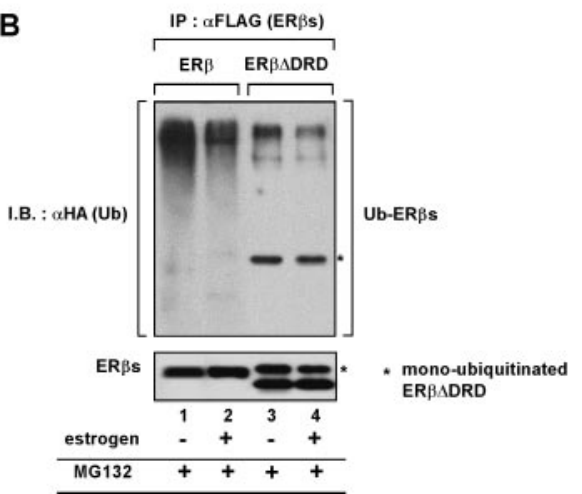

E

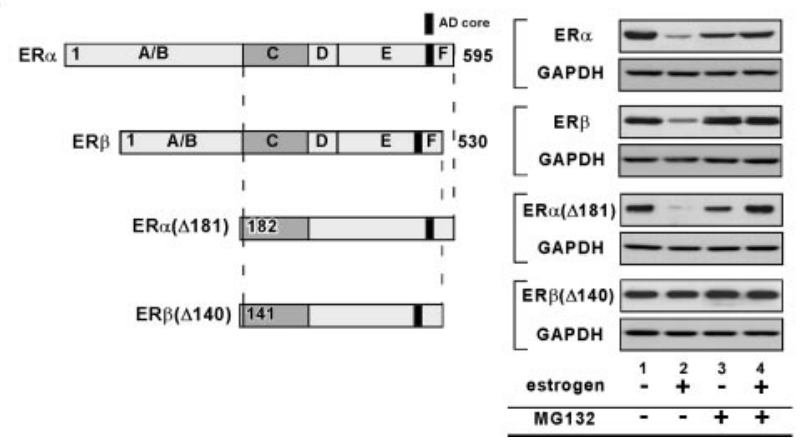

FIG. 1. ER $\beta$ is degraded through ubiquitin-proteasome pathways. (A) ER $\beta$ is degraded in an estrogen-dependent manner. ER $\beta$-transfected MDA-MB-231 cells were cultured in the presence or the absence of estrogen $\left(10^{-8} \mathrm{M}\right)$ and the proteasome inhibitor MG132 $\left(10^{-6} \mathrm{M}\right)$. ER $\beta$ level was analyzed by use of Western blots probed with the indicated antibody. (B) ER $\beta$ is degraded via ubiquitin-proteasome pathways. ER $\beta$-transfected MDA-MB-231 cells were cultured in the presence or the absence of estrogen $\left(10^{-8} \mathrm{M}\right)$ and MG132 $\left(10^{-6} \mathrm{M}\right)$. ER $\beta$ was immunoprecipitated (IP) using anti-ER $\beta$ antibody. Upper panel: the ubiquitination status of ER $\beta$ was analyzed by Western blotting (IB) and probed with an anti-ubiquitin antibody. Lower panel: immunoprecipitated ER $\beta$ was detected by Western blotting and probed with an anti-ER $\beta$ antibody. IgG, immunoglobulin $\mathrm{G} ; \mathrm{M}$, molecular mass. (C) The estrogen-dependent degradation of ER $\beta$ is inhibited by mutated ubiquitin $\mathrm{Ub}(\mathrm{K} 48 \mathrm{R})$. FLAG-tagged ER $\beta$ and DNA encoding HA-Ub (1,000 ng) or HA-Ub(K48R) (1,000 ng) were transfected into 293 cells in the presence or the absence of estrogen $\left(10^{-8} \mathrm{M}\right)$. ER $\beta$ was detected by use of Western blots probed with anti-FLAG-M2 antibody. (D) The polyubiquitin chain of ER $\beta$ is linked via K48. FLAG-tagged ER $\beta$ and DNA encoding HA-Ub (1,000 ng) or HA-Ub(K48R) (1,000 ng) were transfected into 293 cells in the presence or the absence of estrogen $\left(10^{-8} \mathrm{M}\right)$ and MG132 $\left(10^{-6} \mathrm{M}\right)$. FLAG-tagged ER $\beta$ was immunoprecipitated with antiFLAG-M2 antibody. Upper panel: the ubiquitination status of ER $\beta$ was analyzed by use of Western blots probed with anti-HA antibody. Lower panel: immunoprecipitated ER $\beta$ was detected by use of Western blots probed with anti-FLAG antibody. (E) The A/B domain is necessary for the estrogen-dependent degradation of ER $\beta$. DNA (500 ng) encoding the indicated FLAG-tagged ER deletion mutants was transfected into 293 cells. These cells were cultured in the presence or the absence of estrogen $\left(10^{-8} \mathrm{M}\right)$ and MG132 $\left(10^{-6} \mathrm{M}\right)$. To evaluate the protein levels of the ER mutants, Western blot analysis was performed using anti-FLAG-M2 antibody.
FIG. 2. DRD-mediated degradation is involved in the downregulation of ERß-mediated transcription. (A) The N-terminal 37-aminoacid region is essential for estrogen-mediated ER $\beta$ degradation. DNA sequences $(500 \mathrm{ng}$ ) encoding the indicated FLAG-tagged ER $\beta$ deletion mutants were transfected into 293 cells. These cells were cultured in the presence or the absence of estrogen $\left(10^{-8} \mathrm{M}\right)$ and MG132 $\left(10^{-6} \mathrm{M}\right)$. To evaluate the protein levels of the ER $\beta$ mutants, Western blot analysis was performed using an anti-FLAG-M2 antibody. (B) DRD-regulated ubiquitination of ER $\beta$. DNA (500 ng) encoding the indicated FLAG-tagged ER $\beta$ mutants and DNA (1,000 ng) encoding HA-tagged ubiquitin were transfected into 293 cells in the presence or the absence of estrogen $\left(10^{-8} \mathrm{M}\right)$. Upper panel: FLAG-tagged ER $\beta$ mutants were immunoprecipitated (IP) with anti-FLAG-M2 antibody. The ubiquitination status of ER $\beta$ was analyzed by use of Western blots probed with anti-HA antibody. Lower panel: immunoprecipitated ER $\beta$ mutants were detected by use of Western blots probed with an anti-FLAG-M2 antibody. I.B., Western blotting.

ligand-dependent degradation (Fig. 1E). In contrast, truncation of the $\mathrm{A} / \mathrm{B}$ domain of $\operatorname{ER} \beta$, forming $\operatorname{ER} \beta(\Delta 140)$, produced no ligand-dependent degradation, suggesting that the $\mathrm{A} / \mathrm{B}$ domain of ER $\beta$ is necessary for its ligand-dependent degradation (Fig. 1E).

We then investigated the region responsible for the degradation of ER $\beta$. The levels of truncated ER $\beta$ protein in the presence and the absence of estrogen were examined by Western blotting. As shown in Fig. $2 A, \operatorname{ER} \beta(\Delta 20)$, in which the 20 $\mathrm{N}$-terminal amino acids are deleted, was elevated in the pres- 
ence of estrogen compared with wild-type $\operatorname{ER} \beta . \operatorname{ER} \beta(\Delta 37)$ exhibited almost no degradation, indicating that the N-terminal 37 amino acids are essential for the ligand-dependent degradation of ER $\beta$ (Fig. 2A). To assess whether this region is sufficient for the ligand-dependent degradation of ER $\beta$, it was fused to $\operatorname{ER} \beta(\Delta 140)$, which does not contain the $\mathrm{A} / \mathrm{B}$ domain and shows little ligand-dependent degradation. In contrast to that of $\operatorname{ER} \beta(\Delta 140)$, the level of $\operatorname{ER} \beta(\Delta 38-140)$ protein, in which the 37 -amino-acid region is fused to $\operatorname{ER} \beta(\Delta 140)$, was reduced in an estrogen-dependent manner (Fig. 2A). This reduction was abrogated by the addition of MG132, indicating that $\operatorname{ER} \beta(\Delta 38-140)$ is degraded by proteasomal pathways. Interestingly, the degradation of $\operatorname{ER} \beta(\mathrm{mC})$, which has three amino acid substitutions in the DNA-binding domain $(\mathrm{C}$ domain) and has almost no ability to bind DNA (30), was similar to that of wild-type ER $\beta$ (Fig. 2A), indicating that binding to the DNA element is not necessary for ligand-dependent receptor degradation. Similar results were obtained when other cell lines, such as MCF-7 or MDA-MB-231, were used (data not shown). From these observations, we concluded that the $\mathrm{N}$ terminal 37-amino-acid region of ER $\beta$ is involved in its liganddependent degradation and designated this region the DRD. We next determined the ubiquitination status of the truncated forms of ER $\beta$. The DRD deletion accumulated a monoubiquitinated form and showed a reduced level of the polyubiquitinated form (Fig. 2B), suggesting that the DRD is required for the polyubiquitination of ER $\beta$.

Purification and identification of an E3 ubiquitin ligase that specifically binds to the DRD of ERß. To investigate why the DRD induces ubiquitination, we examined two possibilities. First, the DRD may contain a lysine residue that is ubiquitinated by a ubiquitin ligase specific for ER $\beta$. Second, there may be a ubiquitin ligase that specifically recognizes and binds to the DRD to ubiquitinate ER $\beta$.

To test the first possibility, we introduced an amino acid substitution at the lysine residue in the DRD. ER $\beta(\mathrm{K} 4 \mathrm{~A})$, in which the lysine residue in the DRD is replaced by alanine, showed ligand-dependent degradation similar to that of the wild type (Fig. 2A), implying that the lysine residue in the DRD is not a target for ubiquitination. Therefore, we investigated the other possibility.

We generated a GST-fused 37-amino-acid region (GSTDRD) with which to purify proteins that specifically bind to the DRD. Whole-cell extracts prepared from 293 cells were incubated with either GST-DRD or GST. The bound proteins were precipitated with glutathione beads and separated using SDSPAGE (Fig. 3A). Mass fingerprinting methods revealed that the proteins that specifically bound to the DRD were the carboxyl terminus of CHIP, HSP70, and HSP90 (Fig. 3A).

CHIP has E3 ubiquitin ligase activity mediated by its carboxyl-terminal U-box domain and has the ability to bind to chaperones HSP/HSC70 via its tetratricopeptide repeat (TPR) domain $(7,48)$. A pull-down assay showed that recombinant CHIP bound to the GST-DRD (Fig. 3B). A coimmunoprecipitation assay demonstrated specific binding of CHIP and HSP70 to ER $\beta$ in both the absence and the presence of estrogen (Fig. $3 C$ ). ER $\beta \Delta D R D$ showed no ability to bind CHIP (Fig. 3D). Therefore, we tested whether CHIP enhances ER $\beta$ ubiquitination. When ER $\beta$ was coexpressed with CHIP, smeary bands of ubiquitin-conjugated ER $\beta$ products were observed
A

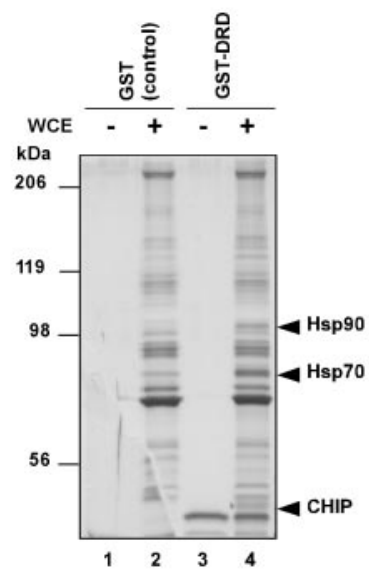

B

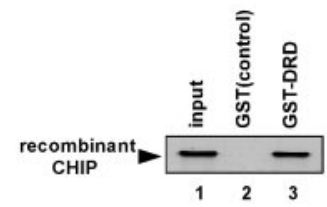

C

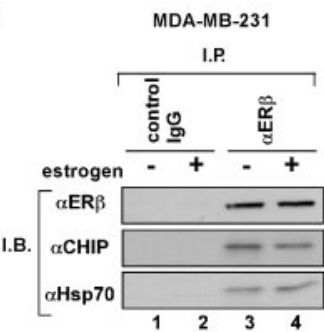

D

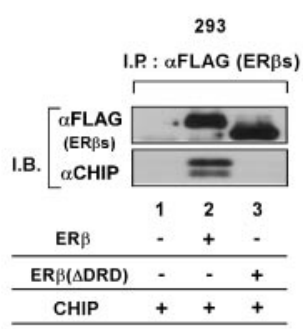

E

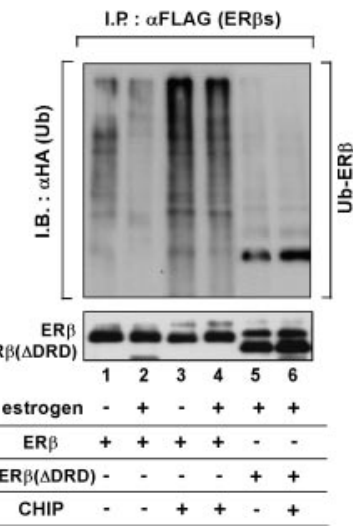

FIG. 3. The DRD associates with a protein complex containing the carboxyl terminus of HSC70-interacting protein (CHIP) and HSC/ HSP70. (A) Purification and identification of DRD-interacting proteins. Whole-cell extracts (WCE) prepared from 293 cells were incubated with GST-DRD or with GST as the control. Bound proteins were precipitated with GST-conjugated beads, eluted with glutathione, and subjected to SDS-PAGE followed by silver staining. The fractions eluted from GST and GST-DRD are shown. Proteins eluted from the DRD peptide were examined by mass spectrometry. (B) CHIP binds the DRD. Recombinant CHIP was incubated with GST-DRD or GST. The bound proteins were precipitated with glutathione beads. CHIP bound to GST-DRD was separated by SDS-PAGE. (C) Interaction between ER $\beta$ and CHIP in vivo. ER $\beta$-transfected MDA-MB-231 cells were lysed and immunoprecipitated (I.P.) with anti-ER $\beta$ antibody in the presence or the absence of estrogen $\left(10^{-8} \mathrm{M}\right)$. The precipitates were Western blotted (I.B.) and probed with antibodies directed against CHIP and HSP70. IgG, immunoglobulin G. (D) DRD is necessary for the interaction between ER $\beta$ and CHIP. ER $\beta$ or $\mathrm{ER} \beta \Delta \mathrm{DRD}$ was transfected into 293 cells. These cells were lysed and immunoprecipitated with anti-FLAG-M2 antibody. The precipitates were Western blotted and probed with antibodies directed against CHIP and HSP70. (E) CHIP induces the ubiquitination of ER $\beta$. DNA (500 ng) encoding FLAG-tagged ER $\beta$ and DNA (1,000 ng) encoding HA-tagged ubiquitin were transfected into 293 cells with or without DNA (50 ng) encoding CHIP in the presence or the absence of estrogen $\left(10^{-8} \mathrm{M}\right)$. FLAG-tagged $\mathrm{ER} \beta$ or $\operatorname{ER} \beta(\Delta \mathrm{DRD})$ was immunoprecipitated using anti-FLAG-M2 antibody. The ubiquitination status of ER $\beta$ was analyzed by use of Western blots probed with anti-HA antibody. 
(Fig. 3E). In contrast, CHIP expression had no effect on the ubiquitination status of $\mathrm{ER} \beta(\Delta \mathrm{DRD})$. Thus, CHIP appears to mediate the ubiquitination of ER $\beta$.

CHIP participates in the degradation of ER $\beta$. ER $\beta$ is known to localize predominantly in the nucleus. Although a large proportion of the CHIP protein was localized in the cytoplasm, a small amount was observed in the nucleus by immunostaining (Fig. 4A) and Western blot analysis (Fig. 4B, left panel). To test whether CHIP-mediated ubiquitination induces the degradation of ER $\beta$, DNA encoding ER $\beta$ was transfected into 293 cells with or without DNA encoding CHIP. Western blot analysis revealed that the steady-state level of ER $\beta$ decreased in both the nucleus and the cytoplasm when CHIP was produced (Fig. 4B, left panel). ER $\beta$ in MDAMB-231 cells also decreased with the production of CHIP (Fig. $4 \mathrm{~B}$, right panel). We further determined CHIP's function by producing MDA-MB-231 cells in which endogenous CHIP expression was suppressed by the introduction of a siRNA complementary to sequences present in the CHIP mRNA. The introduction of the siRNA vector into MDA-MB-231 cells suppressed the expression of CHIP mRNA (data not shown) and protein (Fig. 4C, left panel) and the accumulation of ER $\beta$ protein (Fig. 4C, right panel). In contrast, a control vector failed to alter the CHIP or ER $\beta$ protein levels (Fig. 4C, right panel). Thus, CHIP appears to be involved in estrogen-dependent ER $\beta$ degradation. To confirm this, pulse-chase experiments were performed. In the presence of estrogen, the halflife of ER $\beta$ exceeded $8 \mathrm{~h}$, but it had a half-life of about $4 \mathrm{~h}$ when CHIP was expressed (Fig. 4D).

To confirm that the DRD is necessary for CHIP-dependent ER $\beta$ degradation, DNA sequences encoding truncated forms of ER $\beta$ were transfected into 293 cells with or without DNA encoding CHIP. CHIP expression enhanced the degradation of $\mathrm{ER} \beta, \mathrm{ER} \beta(\mathrm{mC}), \mathrm{ER} \beta(\mathrm{DRD} ; \Delta 140)$, and $\mathrm{ER} \beta(\mathrm{AF}-1)$, all of which contain the DRD, but did not enhance the degradation of $\operatorname{ER} \beta(\Delta D R D)$ or $\operatorname{ER} \beta(\Delta 140)$, neither of which contains the DRD (Fig. 5A). To test the specificity of this effect, we created constructs in which the TPR and U-box domains of CHIP were deleted ( $\triangle \mathrm{TPR}$ and $\triangle \mathrm{U}$-box, respectively). CHIP binds to HSP/HSC70 via its TPR motif and displays E3 ubiquitin ligase activity mediated by its U-box domain. Although the expression of these truncated proteins was similar to that of fulllength CHIP (data not shown), deletion of either of these domains abolished the effects of CHIP on ER $\beta$ (Fig. 5B). Such a requirement for a TPR motif indicates that CHIP may have to interact with $\mathrm{HSP} / \mathrm{HSC} 70$ to promote $\mathrm{ER} \beta$ degradation. The functional requirement for the U-box confirms that CHIP regulates ER $\beta$ ubiquitination.

In a previous report, we showed that CHIP binds $\mathrm{ER} \alpha$ in the absence of estrogen (48). Since ER $\alpha$ and ER $\beta$ heterodimerize readily in the presence of each other, we examined the effect of cointroducing $\mathrm{ER} \alpha$ on CHIP-dependent degradation of ER $\beta$. As shown in Fig. 5C, the degradation of ER $\beta$ was not affected by coexpression of $\mathrm{ER} \alpha$.

The $\mathbf{F}$ domain regulates ER $\beta$ degradation negatively. Our results showed that whereas CHIP binds and ubiquitinates $\mathrm{ER} \beta$ in both the presence and the absence of estrogen, the degradation of ER $\beta$ is estrogen dependent. To investigate this discrepancy, DNA sequences encoding truncated forms of ERs were transfected into 293 cells and the protein levels were
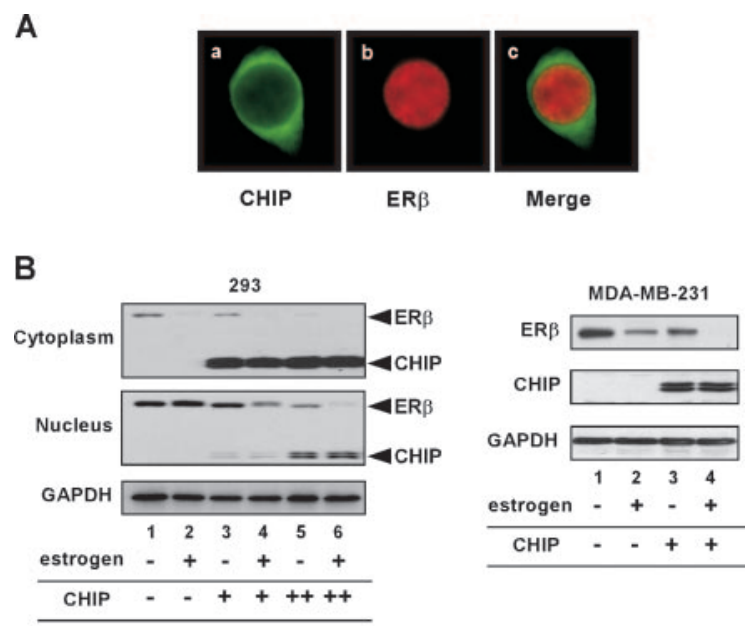

C
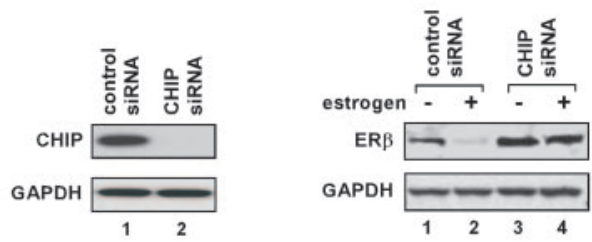

D
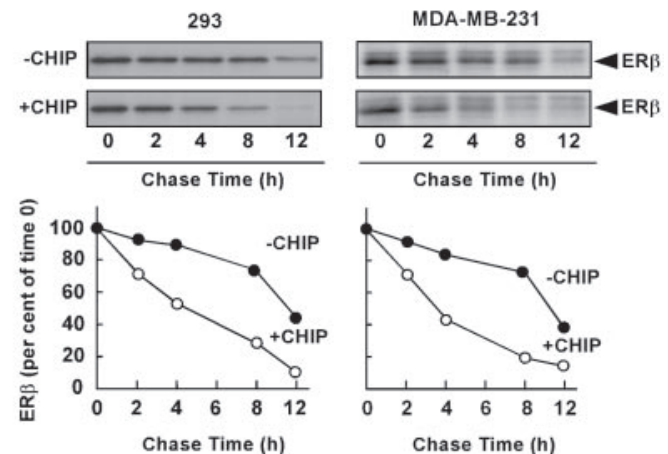

FIG. 4. CHIP enhances the degradation of ER $\beta$. (A) CHIP protein was observed in both the cytoplasm and the nucleus. The 293 cells were transiently transfected with plasmids encoding HA-tagged CHIP and FLAG-tagged ER $\beta$. Mounted cells were examined by immunofluorescence microscopy as described in Materials and Methods. (a) The distribution of CHIP in the cell is shown. (b) The distribution of ER $\beta$ is shown. (c) Merged images of panels a and b. (B) CHIP expression reduced the steady-state level of ER $\beta$. DNA (50 ng) encoding HAtagged CHIP was cotransfected into 293 or MDA-MB-231 cells with DNA (500 ng) encoding FLAG-tagged ER $\beta$ in the absence or the presence of estrogen $\left(10^{-8} \mathrm{M}\right)$. The level of ER $\beta$ protein was examined by use of Western blots probed with anti-FLAG (293) or antiER $\beta$ (MDA-MB-231) antibody. (C) ER $\beta$ accumulated after the siRNA-mediated suppression of endogenous CHIP. Plasmids encoding a siRNA specific for CHIP or the control vector were introduced into MDA-MB-231 cells. These cells were selected with G418. Levels of CHIP and ER $\beta$ proteins were assessed by immunoblotting the whole-cell lysates with specific antibodies, as indicated. (D) CHIP facilitates the degradation of ER $\beta .293$ or MDA-MB-231 cells were transfected with DNA (50 ng) encoding CHIP or with DNA (500 ng) encoding FLAG-tagged ER $\beta$ in the presence of estrogen $\left(10^{-8} \mathrm{M}\right)$. Cells were pulse-labeled with $\left[{ }^{35} \mathrm{~S}\right] \mathrm{methionine}$ and then chased for the indicated times in medium containing unlabeled methionine. ${ }^{35} \mathrm{~S}$-labeled ER $\beta$ in the immunoprecipitate was quantified by phosphorimaging, and the levels in control cells (closed circles) and CHIP-expressing cells (open circles) were plotted relative to the amount present at time zero. 
A

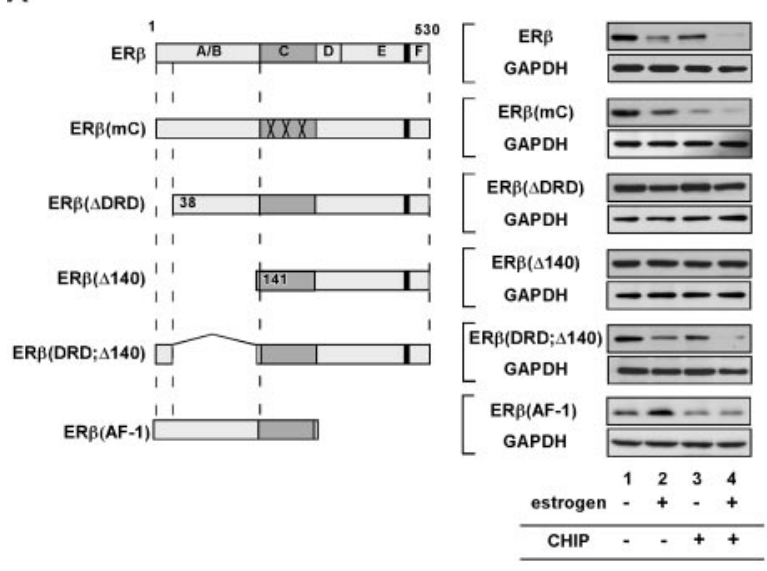

B

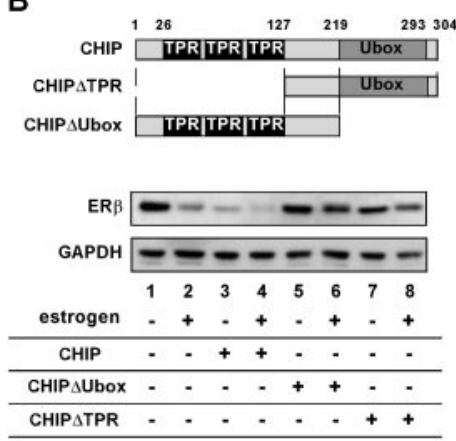

C

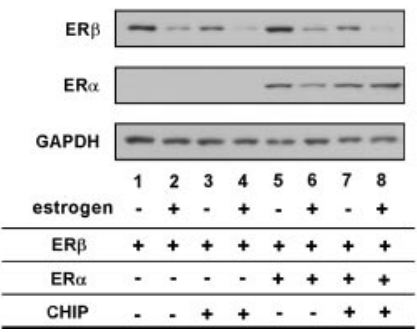

FIG. 5. CHIP regulates DRD-mediated ubiquitination and degradation. (A) The DRD is necessary for CHIP-dependent ER $\beta$ degradation. DNA (500 ng) encoding the indicated FLAG-tagged ER $\beta$ mutants was transfected into 293 cells, with or without DNA encoding CHIP. These cells were cultured in the presence or the absence of estrogen $\left(10^{-8} \mathrm{M}\right)$. To evaluate the levels of ER $\beta$ mutant proteins, Western blot analysis was performed using anti-FLAG-M2 antibody. (B) Both the TPR and U-box domain of CHIP are necessary for ER $\beta$ degradation. DNA (50 ng) encoding CHIP, CHIP $\triangle$ TPR, or CHIP $\Delta$ Ubox was transfected into 293 cells with or without DNA (500 ng) encoding FLAG-tagged ER $\beta$. Levels of ER $\beta$ protein were examined by use of Western blots probed with anti-FLAG-M2 antibody. (C) The CHIP-dependent ER $\beta$ degradation is not affected by ER $\alpha$. DNA (500 ng) encoding FLAG-tagged ER $\beta$ was transfected into 293 cells with or without DNA (500 ng) encoding FLAG-tagged $\mathrm{ER} \alpha$ and DNA (50 ng) encoding CHIP. Levels of ER $\beta$ and ER $\alpha$ protein were examined by use of Western blots probed with anti-FLAG-M2 antibody.

examined. The AD core domain is necessary for estrogendependent degradation of $\operatorname{ER} \alpha(29,48)$. Consistent with this observation, $\mathrm{ER} \alpha(\Delta \mathrm{AD})$ was stabilized by ligand binding and thus accumulated in response to estrogen (Fig. 6A). Interestingly, the deletion of the $\mathrm{AD}$ core of $\mathrm{ER} \beta$ resulted in a dramatic reduction in ER $\beta$ in the absence of estrogen (Fig. 6A). This observation raises the possibility that the C-terminal region of ER $\beta$ is necessary for the stabilization of ER $\beta$. To test this possibility, DNA sequences encoding deletion mutants of the $C$ terminus of ER $\beta$ were transfected into 293 cells and levels of expressed protein were determined by Western blot analysis. When the $\mathrm{F}$ domain was deleted $[\operatorname{ER} \beta(\Delta \mathrm{F})]$, a dramatic reduction in $E R \beta$ protein was observed in the absence of estrogen (Fig. 6B). This reduction in ER $\beta$ was inhibited by MG132, indicating that the $\mathrm{F}$ domain suppresses the proteasome-dependent degradation of ER $\beta$. The degradation of $\operatorname{ER} \beta(\Delta F)$ required the $D R D$, because $\operatorname{ER} \beta(\Delta D R D ; \Delta F)$ was not degraded in the absence of estrogen. In contrast, the degradation of $\operatorname{ER} \beta(\Delta 140 ; \Delta \mathrm{F})$ was enhanced by fusion with the DRD $[\mathrm{ER} \beta(\mathrm{DRD} ; \Delta 140 ; \Delta \mathrm{F})]$ in both the presence and the absence of estrogen (Fig. 6B). These results suggest that the F domain suppresses the DRD-dependent degradation of ER $\beta$ in the absence of estrogen.

In contrast to what was seen for $\mathrm{ER} \beta$, the deletion of the $\mathrm{F}$ domain in $\mathrm{ER} \alpha$ did not affect its degradation. To study this, we generated a chimeric ER $\beta, E R \beta(\alpha F)$, in which the $F$ domain was substituted with an $\mathrm{ER} \alpha \mathrm{F}$ domain. However, there is almost no homology between the ER $\alpha$ F and ER $\beta$ F domains, and the $\mathrm{F}$ domain of $\mathrm{ER} \alpha$ was able to protect $\mathrm{ER} \beta$ from proteolysis in the absence of estrogen (Fig. 6B).

Next, we determined the ubiquitination statuses of ER $\beta$ and $\operatorname{ER} \beta(\Delta F)$. That of $\operatorname{ER} \beta(\Delta F)$ was similar to that of full-length ER $\beta$ (Fig. 7A), indicating that the $F$ domain does not regulate the ubiquitination step of ER $\beta$. Thus, the F domain may inhibit the accession of $26 \mathrm{~S}$ proteasome to ER $\beta$ structurally. Therefore, we evaluated the binding between ER $\beta$ and proteasomes. FLAG-tagged $\operatorname{ER} \beta$ or $\operatorname{ER} \beta(\Delta F)$ was transfected into 293 cells with SUG-1, which is one of the components of regulatory subunit of $26 \mathrm{~S}$ proteasome. A coimmunoprecipitation experiment revealed that deletion of the $\mathrm{F}$ domain enhanced association between ER $\beta$ and SUG-1 (Fig. 7B). In addition, SUG-1 efficiently reduced $\operatorname{ER} \beta(\Delta F)$ rather than $E R \beta$ (Fig. 7C). Thus, in the absence of estrogen, the F domain appears to abrogate the binding of the $26 \mathrm{~S}$ proteasome to ER $\beta$ to protect the receptor from proteolysis.

Receptor degradation is involved in the downregulation of transcription of the gene for ER $\beta$ after ligand withdrawal. Recent evidence indicates that receptor degradation is coupled to transactivation and that the transcriptional activity of the gene for $\mathrm{ER} \alpha$ is abrogated by the addition of MG132. The transcriptional activity of ER $\beta$ was also reduced by MG132 (Fig. 8A). Thus, it is likely that receptor degradation is necessary for the ligand-dependent transactivation of the ER $\beta$ gene. To investigate the association between CHIP-mediated recep- 
A

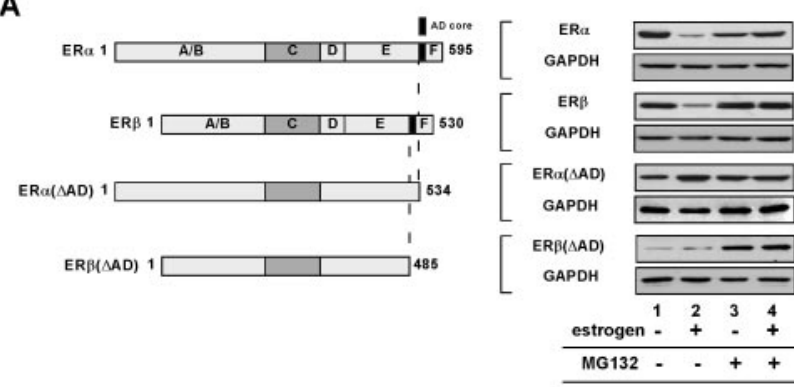

B

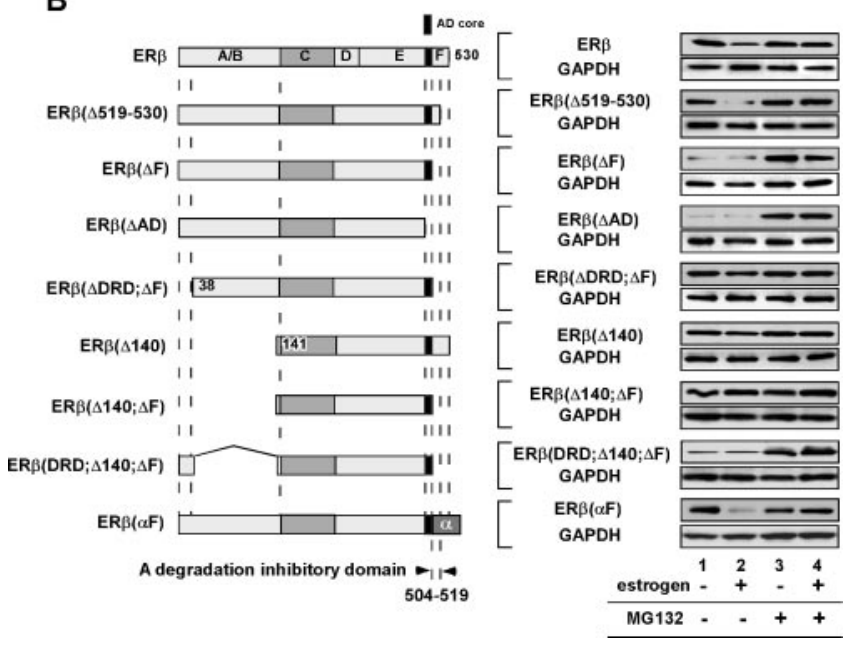

FIG. 6. The F domain suppresses DRD-mediated proteolysis of ER $\beta$. (A) AD core deletion in ER $\beta$ increased the degradation of ligand-unbound receptor. DNA sequences $(500 \mathrm{ng})$ encoding the indicated FLAG-tagged ER deletion mutants were transfected into 293 cells. These cells were cultured in the presence or the absence of estrogen $\left(10^{-8} \mathrm{M}\right)$ and MG132 $\left(10^{-6} \mathrm{M}\right)$. To evaluate the protein levels of the ER mutants, Western blot analysis was performed using anti-FLAG-M2 antibody. (B) F domain protects ER $\beta$ from DRDmediated degradation. DNA sequences (500 $\mathrm{ng}$ ) encoding the indicated FLAG-tagged ER $\beta$ deletion mutants were transfected into 293 cells cultured in the presence or the absence of estrogen $\left(10^{-8} \mathrm{M}\right)$ and MG132 $\left(10^{-6} \mathrm{M}\right)$. To evaluate the protein levels of the ER $\beta$ mutants, Western blot analysis was performed using anti-FLAG-M2 antibody.

tor degradation and transactivation, we evaluated the transcriptional activities of ER $\beta$ deletion mutants by use of a transient reporter assay. As shown in Fig. 8B, ER $\beta(\Delta D R D)$ exhibited a transcriptional activity higher than that of fulllength ER $\beta$. However, $\operatorname{ER} \beta(\Delta 140)$ still showed transcriptional activity. When the DRD was fused to $\operatorname{ER} \beta(\Delta 140)$ to form $\mathrm{ER} \beta(\mathrm{DRD} ; \Delta 140)$, its transcriptional activity was reduced (Fig. 8B). Similarly, $\operatorname{ER} \beta(\Delta 140 ; \Delta \mathrm{F})$ exhibited higher transcriptional activity than $\operatorname{ER} \beta(\Delta \mathrm{F})$, but fusion of DRD decreased its transcriptional activity (Fig. 8B). In agreement with these results, CHIP expression downregulated the transcriptional activity of the ER $\beta$ gene (Fig. 8C). In contrast, CHIP siRNA enhanced transcriptional activity (Fig. $8 \mathrm{C}$ ). The transcriptional activity of $\operatorname{ER} \beta(\Delta \mathrm{DRD})$ was not affected by expression of CHIP (Fig. $8 \mathrm{C}$ ). Overall, our results indicate that CHIP-mediated degradation is not necessary for receptor-mediated transactivation. In addition, CHIP is able to ubiquitinate and to degrade $\mathrm{ER} \beta(\mathrm{mC})$ (Fig. $5 \mathrm{~A}$ ), indicating that binding to the DNA ele-
A

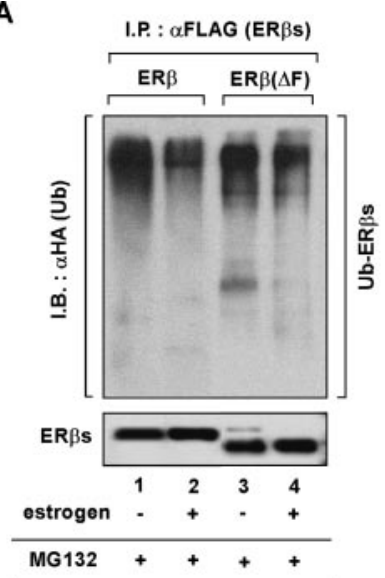

B

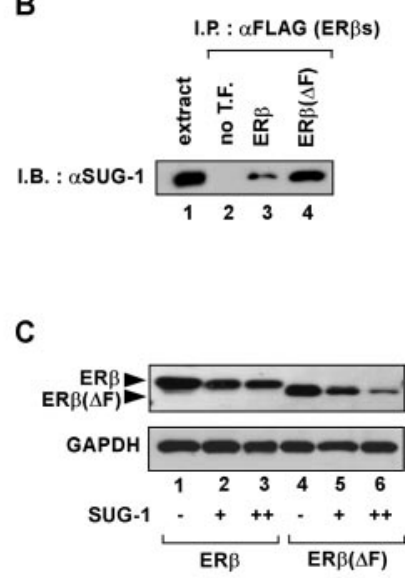

FIG. 7. F domain abrogates the association of proteasomes with ER $\beta$. (A) Deletion of the F domain does not alter the ubiquitination status of ER $\beta$. DNA sequences $(500 \mathrm{ng}$ ) encoding the indicated FLAG-tagged ER $\beta$ mutants and DNA (1,000 ng) encoding HA-tagged ubiquitin were transfected into 293 cells in the presence or the absence of estrogen $\left(10^{-8} \mathrm{M}\right)$. Upper panel: FLAG-tagged ER $\beta$ mutants were immunoprecipitated (I.P.) with anti-FLAG-M2 antibody. The ubiquitination status of ER $\beta$ was analyzed by use of Western blots probed with anti-HA antibody. I.B., Western blotting. Lower panel: immunoprecipitated ER $\beta$ mutants were detected by use of Western blots probed with anti-FLAG antibody. (B) The F domain abrogates the association of SUG-1 with ER $\beta$. DNA sequences (500 ng) encoding either $\operatorname{ER} \beta$ or $\operatorname{ER} \beta(\Delta F)$ were transfected into 293 cells. FLAG-tagged $\mathrm{ER} \beta$ or ER $\beta$ mutants were immunoprecipitated with anti-FLAG-M2 antibody. The precipitates were Western blotted and probed with an antibody against SUG-1. T.F., transfection. (C) The F domain protects ER $\beta$ from SUG-1-dependent degradation. DNA sequences (100 ng) encoding SUG-1 were cotransfected into 293 cells with or without DNA sequences (500 ng) encoding FLAG-tagged $\operatorname{ER} \beta$ or $\operatorname{ER} \beta(\Delta \mathrm{F})$. The levels of ER $\beta$ or $\operatorname{ER} \beta(\Delta \mathrm{F})$ protein were examined by Western blotting and probed with anti-FLAG antibody.

ment is not necessary for CHIP-mediated receptor degradation. These results show that large amounts of liganded ER $\beta$ protein are selectively and rapidly degraded independently of receptor-mediated transcription by CHIP.

To investigate the biological significance of this "wastefulness," we hypothesized that CHIP-mediated degradation selectively and rapidly degrades the active form of ER $\beta$ to shut off ER $\beta$-mediated transcription when the estrogen dose is reduced. To test this hypothesis, we measured the transcriptional activities of constructs encoding $E R \beta$ and $E R \beta(\Delta D R D)$ after estrogen withdrawal. DNA sequences encoding either ER $\beta$ or $\operatorname{ER} \beta(\Delta D R D)$ were transfected into 293 cells together with a plasmid in which the PEST sequence was fused to the luciferase gene (ERE-TATA-LucCP), and the luciferase activity was measured at various time points after estrogen withdrawal. As shown in Fig. 9A, the transcriptional activity of the ER $\beta$ sequence was reduced much faster than that of $\operatorname{ER} \beta(\Delta D R D)$. Using MDA-MB-231 cells that stably express either control siRNA or CHIP siRNA, we tested whether CHIP is involved in the downregulation of ER $\beta$-mediated transcription after reduction of the ligand dose. Plasmids containing the PESTfused luciferase gene were transfected into MDA-MB-231 cells expressing either control siRNA or CHIP siRNA. ER $\beta$ genemediated transcription was downregulated faster in the MDA- 
A

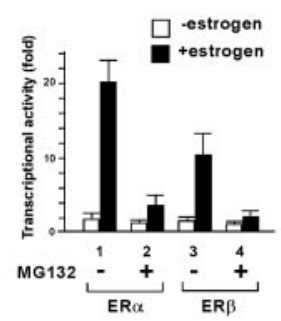

C

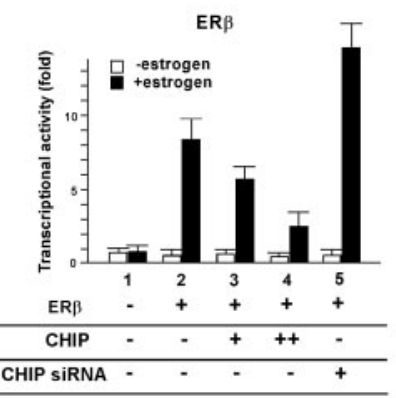

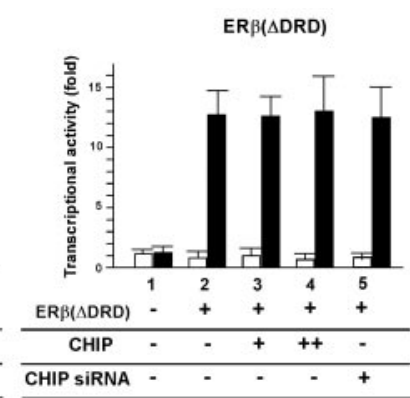

B
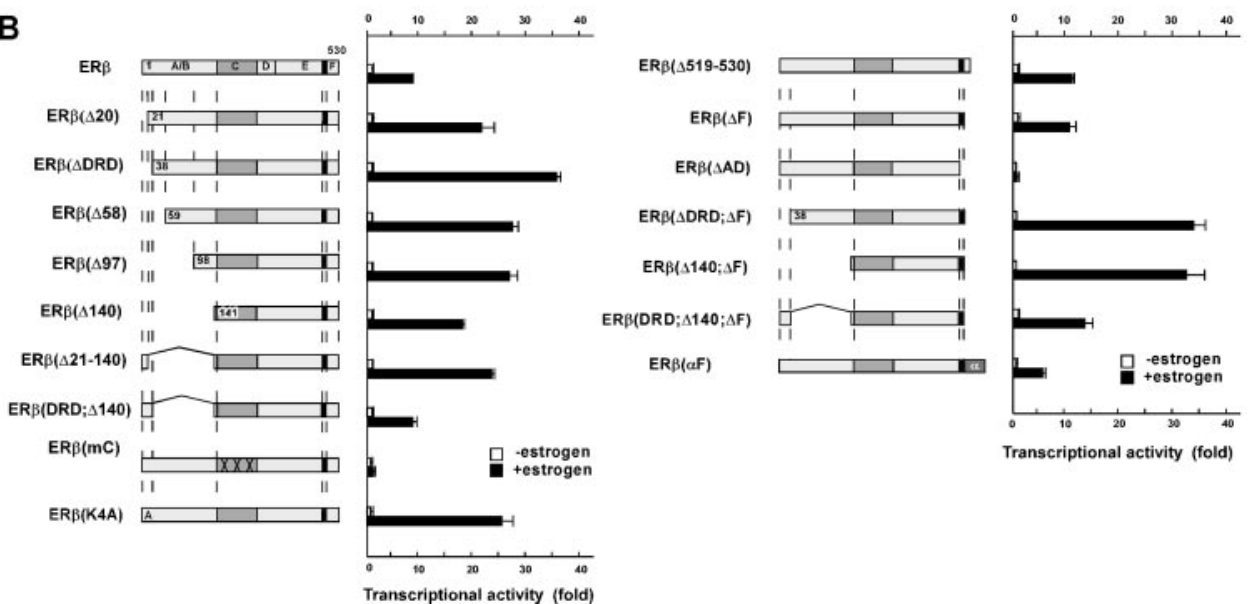

FIG. 8. CHIP decreases transcriptional activity of ER $\beta$ by degradation. (A) Proteasome-dependent degradation is necessary for the transactivation of ERs. DNA sequences (0.05 ng) encoding the ER $\beta$ or ER $\alpha$ were cotransfected into 293 cells with ERE-TATA-Luc (50 ng) and pRSVBGAL (50 ng) in the presence or absence of MG132 $\left(10^{-6} \mathrm{M}\right)$, and the cell extracts were used in a luciferase assay. (B) DRD-mediated degradation is not coupled to ligand-dependent receptor transactivation. DNA sequences $(0.05 \mathrm{ng})$ encoding the indicated ER $\beta$ mutants were cotransfected into 293 cells with ERE-TATA-Luc (50 ng) and pRSVBGAL (50 ng), and the cell extracts were used in a luciferase assay. (C) CHIP production reduced the transcriptional activity of ER $\beta$. ERE-TATA-Luc (50 ng), pRSVBGAL (50 ng), and DNA sequences (0.05 ng) encoding either ER $\beta$ or $\operatorname{ER} \beta(\triangle D R D)$ were cotransfected into 293 cells with or without DNA encoding CHIP and CHIP RNAi, and the cell extracts were used in a luciferase assay.

MB-231 cells expressing control siRNA than in the cells expressing CHIP siRNA (Fig. 9A).

The serum estrogen concentration varies from $1.5 \times 10^{-10}$ $\mathrm{M}$ to $1.8 \times 10^{-9} \mathrm{M}$ during the menstrual cycle. Therefore, we investigated the dose response of the CHIP-dependent degradation of ER $\beta$. As shown in Fig. 9B, CHIP-dependent ER $\beta$ degradation was changed in the levels of estrogen in the blood during the menstrual cycle.

Overall, these results suggest that CHIP-mediated degradation selectively and rapidly eliminates the active form of the NR to downregulate receptor-mediated transcription after ligand withdrawal.

\section{DISCUSSION}

In this study, we have shown that $E R \beta$ is ubiquitinated and degraded in an estrogen-dependent manner. We identified two regions within ER $\beta$ that are essential for the regulation of ER $\beta$ ubiquitination and degradation. The N-terminal 37-amino-acid region, the $\mathrm{DRD}$, is necessary for the polyubiquitination of ER $\beta$. Thus, ER $\beta$ seems to be constitutively exposed to attack by ubiquitin ligases because it contains the DRD. The Cterminal $\mathrm{F}$ domain abrogates DRD-dependent ER $\beta$ degradation, and the ubiquitination status of $\operatorname{ER} \beta(\Delta \mathrm{F})$ was similar to that of full-length ER $\beta$. In addition, coimmunoprecipitation experiments revealed that the $\mathrm{F}$ domain inhibits the binding of unliganded ER $\beta$ to the regulatory subunit of $26 \mathrm{~S}$ proteasome. Thus, the $\mathrm{F}$ domain may regulate not ubiquitination itself but the step involving proteasomal degradation. When estrogen binds to ER $\beta$, the conformation of the C-terminal region, including the $\mathrm{F}$ domain, is changed, and the protective effect of the $\mathrm{F}$ domain is abolished to induce degradation. Some members of the NR superfamily have an F domain, but its function is unknown. Our observations provide the first evidence that the $\mathrm{F}$ domain of ER $\beta$ is involved in the regulation of its proteasome-dependent degradation.

The activation of NRs appears to be coupled to their degradation by the ubiquitin-proteasome pathway $(3,4,8)$. Furthermore, several components of the ubiquitin-proteasome pathway, including SUG1/TRIP1 (17, 27, 32), RSP5/RPF1 (23), E6-AP (37), and UBC9 (42), have been identified as NR-interacting proteins. TBL1/TBLR1, which are components of the NR corepressor complex, also mediate corepressor/ coactivator exchange by the ligand-dependent recruitment of the ubiquitin-19S proteasome complex (40). Thus, the ubiquitin-proteasome pathway appears to play an important role in regulating NR levels and restricting the duration and mag- 
A
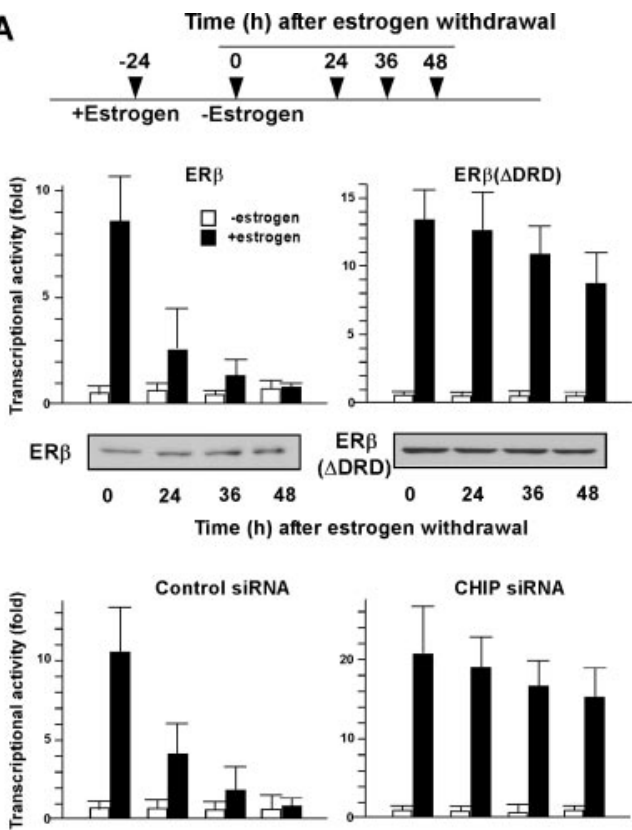

$\begin{array}{llll}0 & 24 & 36 & 48\end{array}$

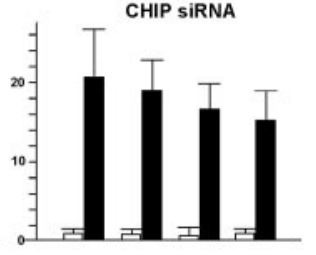

$\begin{array}{llll}0 & 24 & 36 & 48\end{array}$
B

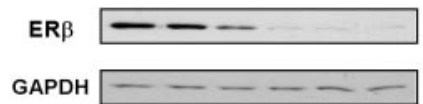

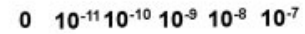

estrogen conc. (M)

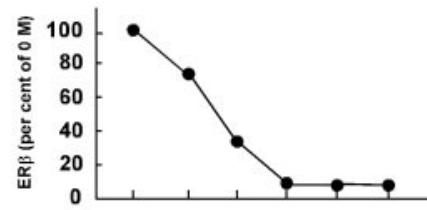

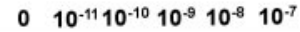

estrogen conc. (M)

FIG. 9. CHIP switches off ER $\beta$-mediated transcription after the estrogen dose is reduced. (A) Downregulation of CHIP inhibits the turning off of ER $\beta$-mediated transcription after estrogen withdrawal. Upper panel: DRD-mediated degradation is involved in the downregulation of ER $\beta$-mediated transcription after estrogen withdrawal. The 293 cells were transfected with expression plasmids encoding FLAG-tagged ER $\beta$ or ER $\beta(\Delta D R D)$, together with ERE-TATA-LucCP (50 ng) and pRSVBGAL (50 ng). Twenty-four hours after transfection, the cells were treated with estrogen (10 $\left.{ }^{-8} \mathrm{M}\right)$ for an additional $24 \mathrm{~h}$, after which the estrogen was withdrawn (time 0 ). These cells were harvested for luciferase assays and Western blotting at the indicated time points after estrogen withdrawal. Lower panel: CHIP is involved in the downregulation of ER $\beta$-mediated transcription when the ligand dose is reduced. Plasmids encoding a siRNA specific for CHIP or control vector were introduced into MDA-MB-231 cells. These cells were selected with G418. FLAG-tagged ERß (100 ng), ERE-TATA-LucCP (400 ng), and pGL3-Control (10 ng) were transfected into these cell lines. Twenty-four hours after transfection, the cells were treated with estrogen $\left(10^{-8} \mathrm{M}\right)$ for an additional $24 \mathrm{~h}$, after which the estrogen was withdrawn (time 0$)$. These cells were harvested for luciferase assays and Western blotting at the times indicated after estrogen withdrawal. (B) Dose-response curve of the estrogen-induced CHIP-dependent degradation of the ER $\beta$. DNA (500 ng) encoding the FLAG-tagged ER $\beta$ was transfected into 293 cells, with or without DNA encoding CHIP. These cells were cultured in the presence of the indicated concentration (conc.) of estrogen (from $10^{-11} \mathrm{M}$ to $10^{-7} \mathrm{M}$ ). Levels of ER $\beta$ protein were examined by use of Western blots probed with anti-FLAG-M2 antibody.

nitude of receptor activity in response to ligands. Furthermore, proteasome-dependent degradation of the steroid receptor requires transcriptional activity, suggesting that receptor degradation and receptor transactivation are mutually interdependent.

Several recent studies have focused on the involvement of the ubiquitin-proteasome pathway in the estrogen-dependent transactivation of $\mathrm{ER} \alpha(14,29,36,44,48,50)$. Moreover, $\mathrm{ER} \alpha$ and its coactivators cycle onto and off of estrogen-responsive promoters in ligand-dependent manners $(35,44,45)$. In this process, $\mathrm{ER} \alpha$ is reportedly ubiquitinated after each round of transcription, facilitating its release from the promoter, which may be essential for subsequent $\mathrm{ER} \alpha$-mediated transcription. We have shown that there is a degradation pathway for ER $\beta$ that is not coupled to transcription. Using $\operatorname{ER} \beta(\Delta \mathrm{DRD})$, we also have shown that transcription-uncoupled receptor degradation is necessary to abolish transcription via the proteolysis of the liganded receptor when the ligand dose is reduced. $\mathrm{ER} \beta(\Delta \mathrm{DRD})$ still exhibited slight ligand-dependent degradation, indicating that there may be other degradation pathways for ER $\beta$. These pathways could be coupled to the transactivation of ER $\beta$.

To investigate the ubiquitin-proteasome pathway for $\mathrm{ER} \beta$, we purified the ubiquitin ligase complex that specifically binds to the DRD and identified a protein complex containing CHIP. CHIP was first reported to induce the ubiquitination of GR bound to HSP90 for proteasomal degradation (7). Recent observations have indicated that CHIP targets a number of HSP70/90-associated proteins for ubiquitination and degradation $(15,18,21,22,28,34,48,52-54)$. We (48) and others (9) have previously shown that CHIP binds unliganded ER $\alpha$ as a protein complex containing HSP90, HSC70, HSP70, HSP40, BAG-1, and BAG-2, all of which possess or assist chaperone functions, and a DnaJ-like protein, KIAA0678. CHIP preferentially induces the hydrolysis of abnormal or mutant forms of $\mathrm{ER} \alpha$, acting as an E3 ubiquitin ligase capable of distinguishing the nonnative states from the native states of the receptor in vivo.

Our results obtained from the analysis of ER $\beta$ suggest that CHIP is involved both in the "quality control" of receptor proteins and in switching off receptor-mediated transcription (Fig. 10). The response of endocrine target tissues to hormones is tightly regulated and is dependent upon circulating levels of available hormonal ligands. When the dose of circulating ligand is reduced, receptor-mediated transcription should be downregulated. The dissociation rate of estrogen 
Quality Control

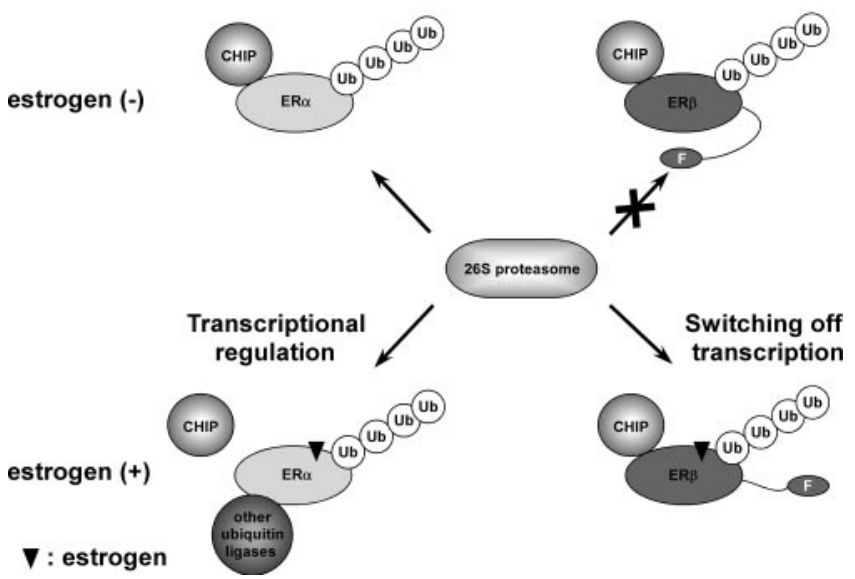

FIG. 10. Schematic representation of the degradation pathways of $E R \alpha$ and $E R \beta . E R \alpha$ binds CHIP in the absence of estrogen. When the estrogen binds $\mathrm{ER} \alpha$, CHIP dissociates. ER $\beta$ binds CHIP in both the absence and the presence of estrogen. In the absence of estrogen, the degradation of ubiquitinated ER $\beta$ is inhibited by the $F$ domain. When the estrogen binds ER $\beta$, the conformation of the $F$ domain is changed to recruit $26 \mathrm{~S}$ proteasome.

from its receptor is very low because a coactivator complex contacts the protein surface above the ligand pocket (16). Thus, it is difficult to cause rapid downregulation by ligand dissociation from its receptor. Our results provide the first evidence that receptor degradation is involved in the cessation of transcription when the ligand dose is reduced. Several nuclear receptors are reported to exhibit agonist-dependent degradation. Therefore, it is possible that other forms of receptor-mediated transcription are downregulated by the same mechanism as ER $\beta$ when the agonist dose is reduced.

$\mathrm{ER} \beta$ is subject to proteasome-mediated degradation in the presence of estrogen, which subsequently limits transcriptional output of ER $\beta$ regardless of whether estrogen is removed or persistently available. As shown in Fig. 8C, CHIP downregulates the ER $\beta$-mediated transactivation in the presence of estrogen. Thus, the CHIP-dependent degradation is involved both in the downregulation of ER $\beta$ activity and in switching off ER $\beta$-mediated transcription.

\section{REFERENCES}

1. Ballinger, C. A., P. Connell, Y. Wu, Z. Hu, L. J. Thompson, L. Y. Yin, and C. Patterson. 1999. Identification of CHIP, a novel tetratricopeptide repeatcontaining protein that interacts with heat shock proteins and negatively regulates chaperone functions. Mol. Cell. Biol. 19:4535-4545.

2. Beato, M., P. Herrlich, and G. Schutz. 1995. Steroid hormone receptors: many actors in search of a plot. Cell 83:851-857.

3. Blanquart, C., O. Barbier, J. C. Fruchart, B. Staels, and C. Glineur. 2002. Peroxisome proliferator-activated receptor alpha (PPARalpha) turnover by the ubiquitin-proteasome system controls the ligand-induced expression level of its target genes. J. Biol. Chem. 277:37254-37259.

4. Boudjelal, M., Z. Wang, J. J. Voorhees, and G. J. Fisher. 2000. Ubiquitin/ proteasome pathway regulates levels of retinoic acid receptor gamma an retinoid X receptor alpha in human keratinocytes. Cancer Res. 60:22472252.

5. Chambon, P. 1996. A decade of molecular biology of retinoic acid receptors. FASEB J. 10:940-954.

6. Cheskis, B. J., N. J. McKenna, C. W. Wong, J. Wong, B. Komm, C. R. Lyttle, and B. W. O'Malley. 2003. Hierarchical affinities and a bipartite interaction model for estrogen receptor isoforms and full-length steroid receptor coactivator (SRC/p160) family members. J. Biol. Chem. 278:13271-13277.

7. Connell, P., C. A. Ballinger, J. Jiang, Y. Wu, L. J. Thompson, J. Hohfeld, and
C. Patterson. 2001. The co-chaperone CHIP regulates protein triage decisions mediated by heat-shock proteins. Nat. Cell Biol. 3:93-96.

8. Dace, A., L. Zhao, K. S. Park, T. Furuno, N. Takamura, M. Nakanishi, B. L. West, J. A. Hanover, and S. Cheng. 2000. Hormone binding induces rapid proteasome-mediated degradation of thyroid hormone receptors. Proc. Natl. Acad. Sci. USA 97:8985-8990.

9. Dai, Q., S. B. Qian, H. H. Li, H. McDonough, C. Borchers, D. Huang, S. Takayama, J. M. Younger, H. Y. Ren, D. M. Cyr, and C. Patterson. 2005. Regulation of the cytoplasmic quality control protein degradation pathway by BAG2. J. Biol. Chem. 280:38673-38681.

10. DeMayo, F. J., B. Zhao, N. Takamoto, and S. Y. Tsai. 2002. Mechanisms of action of estrogen and progesterone. Ann. N. Y. Acad. Sci. 955:48-59, 86-88, 396-406.

11. Dennis, A. P., R. U. Haq, and Z. Nawaz. 2001. Importance of the regulation of nuclear receptor degradation. Front. Biosci. 6:D954-D959.

12. Deroo, B. J., and K. S. Korach. 2006. Estrogen receptors and human disease. J. Clin. Investig. 116:561-570.

13. Deroo, B. J., C. Rentsch, S. Sampath, J. Young, D. B. DeFranco, and T. K. Archer. 2002. Proteasomal inhibition enhances glucocorticoid receptor transactivation and alters its subnuclear trafficking. Mol. Cell. Biol. 22:41134123 .

14. Fan, M., A. Park, and K. P. Nephew. 2005. CHIP (carboxyl terminus of Hsc70-interacting protein) promotes basal and geldanamycin-induced degradation of estrogen receptor-alpha. Mol. Endocrinol. 19:2901-2914.

15. Galigniana, M. D., J. M. Harrell, P. R. Housley, C. Patterson, S. K. Fisher, and W. B. Pratt. 2004. Retrograde transport of the glucocorticoid receptor in neurites requires dynamic assembly of complexes with the protein chaperone hsp90 and is linked to the CHIP component of the machinery for proteasomal degradation. Brain Res. Mol. Brain Res. 123:27-36.

16. Gee, A. C., K. E. Carlson, P. G. Martini, B. S. Katzenellenbogen, and J. A. Katzenellenbogen. 1999. Coactivator peptides have a differential stabilizing effect on the binding of estrogens and antiestrogens with the estrogen receptor. Mol. Endocrinol. 13:1912-1923.

17. Gianni, M., A. Bauer, E. Garattini, P. Chambon, and C. Rochette-Egly. 2002. Phosphorylation by p38MAPK and recruitment of SUG-1 are required for RA-induced RAR gamma degradation and transactivation. EMBO J. 21: 3760-3769.

18. He, B., S. Bai, A. T. Hnat, R. I. Kalman, J. T. Minges, C. Patterson, and E. M. Wilson. 2004. An androgen receptor NH2-terminal conserved motif interacts with the $\mathrm{COOH}$ terminus of the Hsp70-interacting protein (CHIP). J. Biol. Chem. 279:30643-30653.

19. Heery, D. M., E. Kalkhoven, S. Hoare, and M. G. Parker. 1997. A signature motif in transcriptional co-activators mediates binding to nuclear receptors. Nature 387:733-736.

20. Hewitt, S. C., and K. S. Korach. 2002. Estrogen receptors: structure, mechanisms and function. Rev. Endocr. Metab. Disord. 3:193-200.

21. Hohfeld, J., D. M. Cyr, and C. Patterson. 2001. From the cradle to the grave: molecular chaperones that may choose between folding and degradation. EMBO Rep. 2:885-890.

22. Imai, Y., M. Soda, S. Hatakeyama, T. Akagi, T. Hashikawa, K. I. Nakayama, and R. Takahashi. 2002. CHIP is associated with Parkin, a gene responsible for familial Parkinson's disease, and enhances its ubiquitin ligase activity. Mol. Cell 10:55-67.

23. Imhof, M. O., and D. P. McDonnell. 1996. Yeast RSP5 and its human homolog hRPF1 potentiate hormone-dependent activation of transcription by human progesterone and glucocorticoid receptors. Mol. Cell. Biol. 16: 2594-2605.

24. Ito, M., C. X. Yuan, H. J. Okano, R. B. Darnell, and R. G. Roeder. 2000. Involvement of the TRAP220 component of the TRAP/SMCC coactivator complex in embryonic development and thyroid hormone action. Mol. Cell 5:683-693.

25. Kamei, Y., L. Xu, T. Heinzel, J. Torchia, R. Kurokawa, B. Gloss, S. C. Lin, R. A. Heyman, D. W. Rose, C. K. Glass, and M. G. Rosenfeld. 1996. A CBP integrator complex mediates transcriptional activation and AP-1 inhibition by nuclear receptors. Cell 85:403-414.

26. Lange, C. A., T. Shen, and K. B. Horwitz. 2000. Phosphorylation of human progesterone receptors at serine-294 by mitogen-activated protein kinase signals their degradation by the $26 \mathrm{~S}$ proteasome. Proc. Natl. Acad. Sci. USA 97:1032-1037.

27. Lee, J. W., F. Ryan, J. C. Swaffield, S. A. Johnston, and D. D. Moore. 1995 Interaction of thyroid-hormone receptor with a conserved transcriptional mediator. Nature 374:91-94.

28. Li, L., H. Xin, X. Xu, M. Huang, X. Zhang, Y. Chen, S. Zhang, X. Y. Fu, and Z. Chang. 2004. CHIP mediates degradation of Smad proteins and potentially regulates Smad-induced transcription. Mol. Cell. Biol. 24:856-864.

29. Lonard, D. M., Z. Nawaz, C. L. Smith, and B. W. O'Malley. 2000. The $26 \mathrm{~S}$ proteasome is required for estrogen receptor-alpha and coactivator turnover and for efficient estrogen receptor-alpha transactivation. Mol. Cell 5:939948.

30. Mader, S., V. Kumar, H. de Verneuil, and P. Chambon. 1989. Three amino acids of the oestrogen receptor are essential to its ability to distinguish an oestrogen from a glucocorticoid-responsive element. Nature 338:271-274. 
31. Mangelsdorf, D. J., C. Thummel, M. Beato, P. Herrlich, G. Schutz, K Umesono, B. Blumberg, P. Kastner, M. Mark, P. Chambon, et al. 1995. The nuclear receptor superfamily: the second decade. Cell 83:835-839.

32. Masuyama, H., and P. N. MacDonald. 1998. Proteasome-mediated degradation of the vitamin $\mathrm{D}$ receptor (VDR) and a putative role for SUG interaction with the AF-2 domain of VDR. J. Cell. Biochem. 71:429-440.

33. McKenna, N. J., and B. W. O'Malley. 2002. Combinatorial control of gene expression by nuclear receptors and coregulators. Cell 108:465-474.

34. Meacham, G. C., C. Patterson, W. Zhang, J. M. Younger, and D. M. Cyr 2001. The Hsc70 co-chaperone CHIP targets immature CFTR for proteasomal degradation. Nat. Cell Biol. 3:100-105.

35. Metivier, R., G. Penot, M. R. Hubner, G. Reid, H. Brand, M. Kos, and F. Gannon. 2003. Estrogen receptor-alpha directs ordered, cyclical, and combinatorial recruitment of cofactors on a natural target promoter. Cell 115: 751-763.

36. Nawaz, Z., D. M. Lonard, A. P. Dennis, C. L. Smith, and B. W. O'Malley. 1999. Proteasome-dependent degradation of the human estrogen receptor Proc. Natl. Acad. Sci. USA 96:1858-1862.

37. Nawaz, Z., D. M. Lonard, C. L. Smith, E. Lev-Lehman, S. Y. Tsai, M. J. Tsai, and B. W. O'Malley. 1999. The Angelman syndrome-associated protein, E6-AP, is a coactivator for the nuclear hormone receptor superfamily. Mol. Cell. Biol. 19:1182-1189.

38. Nawaz, Z., and B. W. O'Malley. 2004. Urban renewal in the nucleus: is protein turnover by proteasomes absolutely required for nuclear receptorregulated transcription? Mol. Endocrinol. 18:493-499.

39. Onate, S. A., S. Y. Tsai, M. J. Tsai, and B. W. O'Malley. 1995. Sequence and characterization of a coactivator for the steroid hormone receptor superfamily. Science 270:1354-1357.

40. Perissi, V., A. Aggarwal, C. K. Glass, D. W. Rose, and M. G. Rosenfeld. 2004 A corepressor/coactivator exchange complex required for transcriptional activation by nuclear receptors and other regulated transcription factors. Cell 116:511-526.

41. Pettersson, K., and J. A. Gustafsson. 2001. Role of estrogen receptor beta in estrogen action. Annu. Rev. Physiol. 63:165-192.

42. Poukka, H., P. Aarnisalo, U. Karvonen, J. J. Palvimo, and O. A. Janne. 1999. Ubc9 interacts with the androgen receptor and activates receptor-dependent transcription. J. Biol. Chem. 274:19441-19446.

43. Rachez, C., B. D. Lemon, Z. Suldan, V. Bromleigh, M. Gamble, A. M. Naar, H. Erdjument-Bromage, P. Tempst, and L. P. Freedman. 1999. Liganddependent transcription activation by nuclear receptors requires the DRIP complex. Nature 398:824-828.

44. Reid, G., M. R. Hubner, R. Metivier, H. Brand, S. Denger, D. Manu, J. Beaudouin, J. Ellenberg, and F. Gannon. 2003. Cyclic, proteasome-mediated turnover of unliganded and liganded ERalpha on responsive promoters is an integral feature of estrogen signaling. Mol. Cell 11:695-707.

45. Shang, Y., X. Hu, J. DiRenzo, M. A. Lazar, and M. Brown. 2000. Cofactor dynamics and sufficiency in estrogen receptor-regulated transcription. Cell 103: $843-852$.

46. Shiau, A. K., D. Barstad, P. M. Loria, L. Cheng, P. J. Kushner, D. A. Agard, and G. L. Greene. 1998. The structural basis of estrogen receptor/coactivator recognition and the antagonism of this interaction by tamoxifen. Cell 95: 927-937.

47. Tanaka, T., M. L. Rodriguez de la Concepcion, and L. M. De Luca. 2001. Involvement of all-trans-retinoic acid in the breakdown of retinoic acid receptors alpha and gamma through proteasomes in MCF-7 human breast cancer cells. Biochem. Pharmacol. 61:1347-1355.

48. Tateishi, Y., Y. Kawabe, T. Chiba, S. Murata, K. Ichikawa, A. Murayama, K. Tanaka, T. Baba, S. Kato, and J. Yanagisawa. 2004. Ligand-dependent switching of ubiquitin-proteasome pathways for estrogen receptor. EMBO J. 23:4813-4823.

49. Tontonoz, P., and D. J. Mangelsdorf. 2003. Liver X receptor signaling pathways in cardiovascular disease. Mol. Endocrinol. 17:985-993.

50. Valley, C. C., R. Metivier, N. M. Solodin, A. M. Fowler, M. T. Mashek, L. Hill, and E. T. Alarid. 2005. Differential regulation of estrogen-inducible proteolysis and transcription by the estrogen receptor alpha $\mathrm{N}$ terminus. Mol. Cell. Biol. 25:5417-5428.

51. Wallace, A. D., and J. A. Cidlowski. 2001. Proteasome-mediated glucocorticoid receptor degradation restricts transcriptional signaling by glucocorticoids. J. Biol. Chem. 276:42714-42721.

52. Wang, X., and D. B. DeFranco. 2005. Alternative effects of the ubiquitinproteasome pathway on glucocorticoid receptor down-regulation and transactivation are mediated by CHIP, an E3 ligase. Mol. Endocrinol. 19:14741482.

53. Wickner, S., M. R. Maurizi, and S. Gottesman. 1999. Posttranslational quality control: folding, refolding, and degrading proteins. Science 286: 1888-1893.

54. Xin, H., X. Xu, L. Li, H. Ning, Y. Rong, Y. Shang, Y. Wang, X. Y. Fu, and Z. Chang. 2005. CHIP controls the sensitivity of transforming growth factorbeta signaling by modulating the basal level of Smad3 through ubiquitinmediated degradation. J. Biol. Chem. 280:20842-20850.

55. Yanagisawa, J., H. Kitagawa, M. Yanagida, O. Wada, S. Ogawa, M. Nakagomi, H. Oishi, Y. Yamamoto, H. Nagasawa, S. B. McMahon, M. D. Cole, L. Tora, N. Takahashi, and S. Kato. 2002. Nuclear receptor function requires a TFTC-type histone acetyl transferase complex. Mol. Cell 9:553-562.

56. Yanagisawa, J., Y. Yanagi, Y. Masuhiro, M. Suzawa, M. Watanabe, K. Kashiwagi, T. Toriyabe, M. Kawabata, K. Miyazono, and S. Kato. 1999 Convergence of transforming growth factor-beta and vitamin D signaling pathways on SMAD transcriptional coactivators. Science 283:1317-1321.

57. Zhu, J., M. Gianni, E. Kopf, N. Honore, M. Chelbi-Alix, M. Koken, F. Quignon, C. Rochette-Egly, and H. de The. 1999. Retinoic acid induces proteasome-dependent degradation of retinoic acid receptor alpha (RARalpha) and oncogenic RARalpha fusion proteins. Proc. Natl. Acad. Sci. USA 96: 14807-14812. 